\title{
Acetoacetic Acid Measurement
}

National Cancer Institute

\section{Source}

National Cancer Institute. Acetoacetic Acid Measurement. NCI Thesaurus. Code C92247.

The determination of the amount of acetoacetic acid present in a sample. 